Syntax Fusion: Jurnal Nasional Indonesia

e-ISSN: $2775-4440$

Vol. 1, No. 10, Oktober 2021

\title{
SISTEM PEMESANAN CATERING BERBASIS WEB PADA PT. CATERING SERVIS UTAMA
}

\section{Gibran Taufan, Nina Meliana}

STMIK Muhammadiyah Jakarta, Indonesia.

Email: gibrantaufan2507@gmail.com,nmeliana2805@gmail.com

\begin{abstract}
Abstrak
PT. Catering Servis Utama merupakan perusahaan yang fokus pada bidang pemesanan makanan untuk berbagai acara yang dilakukan di rumah maupun di gedung. Dalam menjalankan usaha catering tersebut, promosi dan informasi layanan catering masih dilakukan hanya mengandalkan brosur serta nomor telepon yang tercatat pada brosur. Hal tersebut membuat perusahaan sulit bersaing dengan perusahaan catering lain yang sudah lebih baik. Melihat kondisi tersebut penulis bermaksud mengadakan penelitian yang bertujuan untuk memberikan solusi melalui studi lapangan dan studi kepustakaan dalam rangka membangun Sistem Pemesanan Catering Berbasis Web pada PT. Catering Servis Utama. Hasil dari penelitian ini penulis dapat membuat sistem pemesanan catering berbasis web yang dapat mempermudah konsumen dalam melakukan pemesanan catering dan pembuatan laporan bulanan yang menginformasikan data pemesanan konsumen. Sistem informasi ini juga memudahkan konsumen maupun Admin dalam melakukan rangkaian proses pemesanan catering dari mulai input data pribadi konsumen hingga proses pemesanan catering secara online, sehingga diharapkan dapat meningkatkan layanan perusahaan dan dapat meningkatkan pemasukan keuangan serta perusahaan semakin berkembang.
\end{abstract}

Kata Kunci: Sistem Informasi; Pemesanan; Catering

Diterima: 30-09-2021 Direvisi: 15-10-2021 Disetujui: 18-10-2021

\section{Pendahuluan}

Perkembangan teknologi saat ini memberikan pengaruh yang sangat besar dan pesat bagi dunia teknologi informasi dan komunikasi, pemesanan makanan pada bidang kuliner adalah suatu hal yang penting untuk masyarakat dalam melakukan acara seperti pernikahan atau acara keluarga. Pada era digital pada saat ini diperlukan cara-cara yang lebih mudah untuk masyarakat dalam hal pemesanan (Azhar, 2013).

PT. Catering Service Utama adalah perusahaan yang bergerak dibidang catering yang berlokasi di daerah Pasar Minggu Jakarta Selatan, Jalan Tanjung Barat Raya, RT.11/RW,8. Pasar Minggu. Lokasinya mudah dicari dan harga catering yang murah. 
Sistem pemesanan catering ini masih menggunakan cara manual sehingga pelanggan harus datang langsung ke tempat catering dan melakukan pemesanan makanan (Sutarman, n.d.).

Berdasarkan beberapa kendala yang diuraikan di atas, memberikan inspirasi kepada Penulis untuk melakukan penelitian yang disajikan dalam bentuk skripsi. Penulis dapat membuat sistem pemesanan makanan untuk memudahkan proses pekerjaan di dalam lingkungan PT. Catering Servis Utama.

Pengguna Media Web pada PT. Catering Service Utama akan lebih mudah dalam melakukan proses pemesanan karena pelanggan langsung bisa membuka web melalui komputer dan bisa melihat menu yang ada di web tersebut, sehingga tidak perlu lagi untuk datang dan pesan secara manual (Sasongko \& Diartono, 2009).

\section{Metodologi Penelitian}

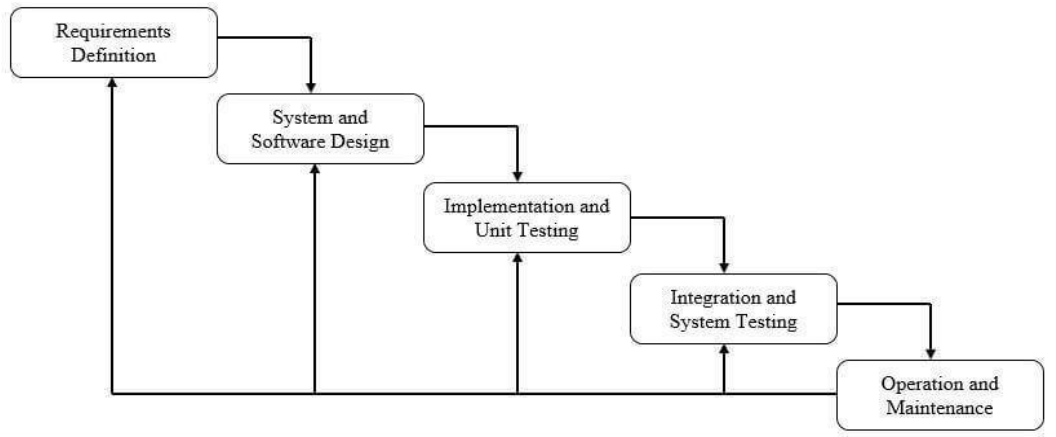

\section{Gambar 1. Metode Waterfall}

Metode waterfall atau metode air terjun merupakan salah satu siklus hidup klasic (classic life cycle) dalam pengembangan perangkat lunak. Ian Sommerville menjelaskan bahwa ada lima tahapan pada Metode Waterfall, yakni Requirements Analysis and Definition, System and Software Design, Implementation and Unit Testing, Integration and System Testing, dan Operations and Maintenance (Ian Sommerville, 2011).

Metode waterfall terdiri dari 5 tahapan yaitu:

\section{Requirement Definition}

Sebelum melakukan pengembangan perangkat lunak, seorang pengembang harus mengetahui dan memahami bagaimana informasi kebutuhan pengguna terhadap sebuah perangkat lunak.

\section{System and Software Design}

Informasi mengenai spesifikasi kebutuhan dari tahap Requirement Analysis selanjutnya di analisa pada tahap ini untuk kemudian diimplementasikan pada desain pengembangan. Perancangan desain dilakukan dengan tujuan membantu memberikan gambaran lengkap mengenai apa yang harus dikerjakan.

3. implementation and unit testing

Tahap implementation and unit testing merupakan tahap pemrograman. Pembuatan perangkat lunak dibagi menjadi modul-modul kecil yang nantinya akan digabungkan dalam tahap berikutnya. 


\section{Integration and System Testing}

Setelah seluruh unit atau modul yang dikembangkan dan diuji di tahap implementasi selanjutnya diintegrasikan dalam sistem secara keseluruhan.

\section{Operation dan Maintenance}

Pada tahap terakhir dalam Metode Waterfall, perangkat lunak yang sudah jadi dioperasikan pengguna dan dilakukan pemeliharaan.

\section{Hasil Dan Pembahasan}

\section{Analisa kebutuhan perangkat keras}

Adapun kebutuhan minimum dan yang disarankan untuk menggunakan aplikasi Sistem Informasi Pengolahan Data Nilai Berbasis Web pada SMK Swadaya Temanggung adalah sebagai berikut:

Tabel 1. Kebutuhan perangkat keras (Hardware)

\begin{tabular}{lll}
\hline \multicolumn{1}{c}{ Perangkat Keras } & \multicolumn{1}{c}{ Kebutuhan Minimum } & \multicolumn{1}{c}{ Kebutuhan Yang Disarankan } \\
\hline Processor & 1.2 Gigahertz $(\mathrm{GHz})$ & Diatas 1.2 Gigahertz $(\mathrm{GHz})$ \\
\hline Memori RAM & $2 \mathrm{gb}$ & 2gb atau lebih \\
\hline Harddisk & $100 \mathrm{gb}$ & 256gb atau lebih \\
\hline Keyboard & Standar & Standar \\
\hline Moused & Standar & Standar \\
\hline
\end{tabular}

\section{Analisa kebutuhan perangkat lunak}

Adapun perangkat lunak untuk membangun program ini adalah sebagai berikut:

Tabel 2. Kebutuhan perangkat lunak (Software)

\begin{tabular}{ll}
\hline \multicolumn{1}{c}{ Perangkat Lunak } & \multicolumn{1}{c}{ Keterangan } \\
\hline Microsoft Windows 10 & Sebagai Sistem Operasi \\
\hline MySQL & Sebagai Pembuatan Database \\
\hline PHP & Sebagai Pembuatan Sistem \\
\hline
\end{tabular}

\section{Analisa Sistem Yang Berjalan}

Sistem pengolahan data nilai saat ini digunakan pada PT. Catering Service Utama masih manual mengalami beberapa kendala seperti keterlambatan pengumpulan data, penyimpanan data yang bertumpuk sehingga ada beberapa data yang hilang 


\section{Sistem Yang Diusulkan}

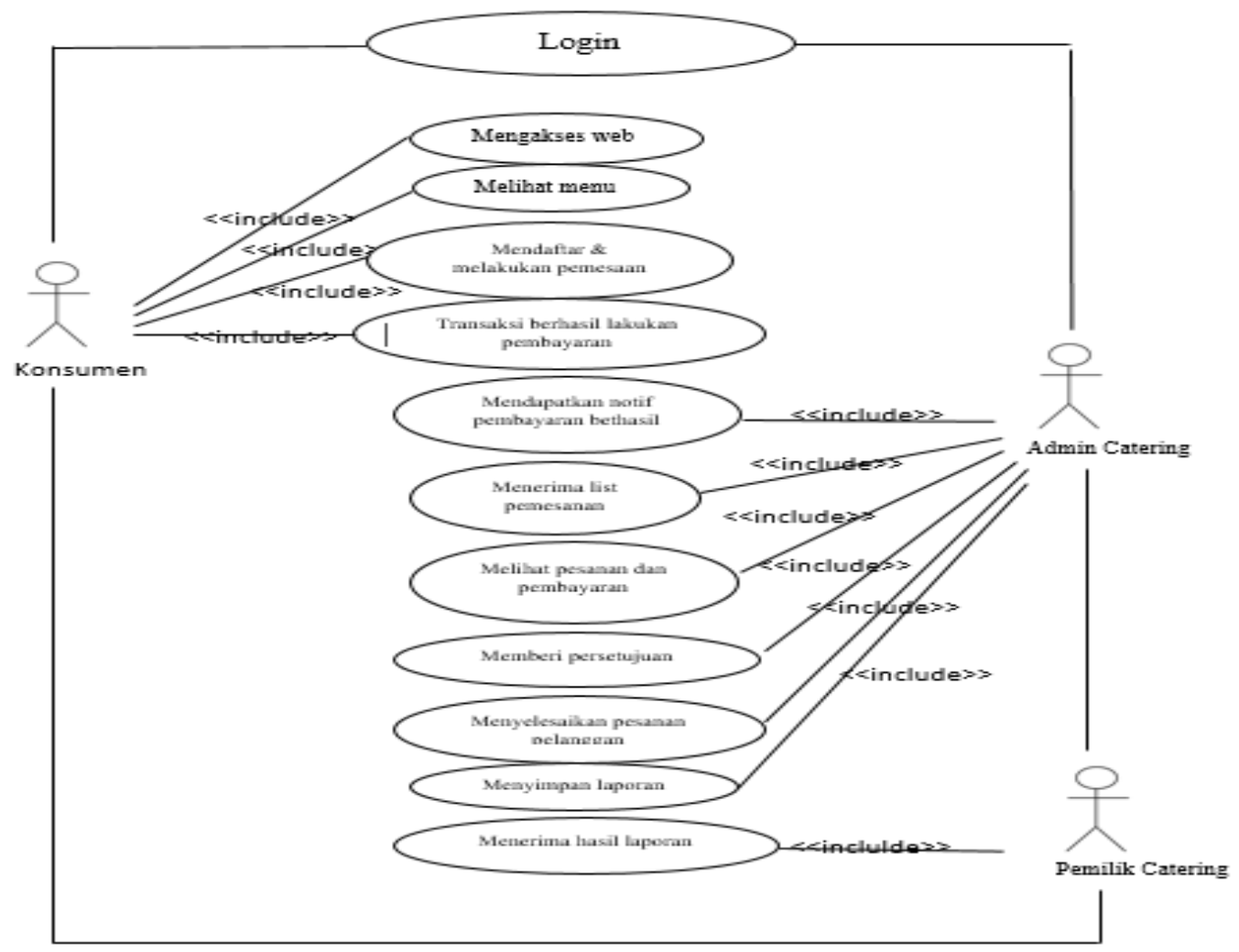

Gambar 3. Sistem yang diusulkan

Pada analisa yang diusulkan, terdapat tiga faktor yaitu: konsumen, admin catering dan pemilik catering.Konsumen bisa memesan di web tersebut sedangkan admin catering bertugas mengatur jalannya pesanan catering tersebut dan pemilik catering hanya bertugas menerima hasil laporan (Kadir, 2002).

\section{Implementasi}

a. Tampilan Halaman Konsumen

Halaman konsumen pada sistem pemesanan catering berbasis web pada PT. Catering Servis Utama, saat konsumen membuka web home awal seperti di gambar ini. 


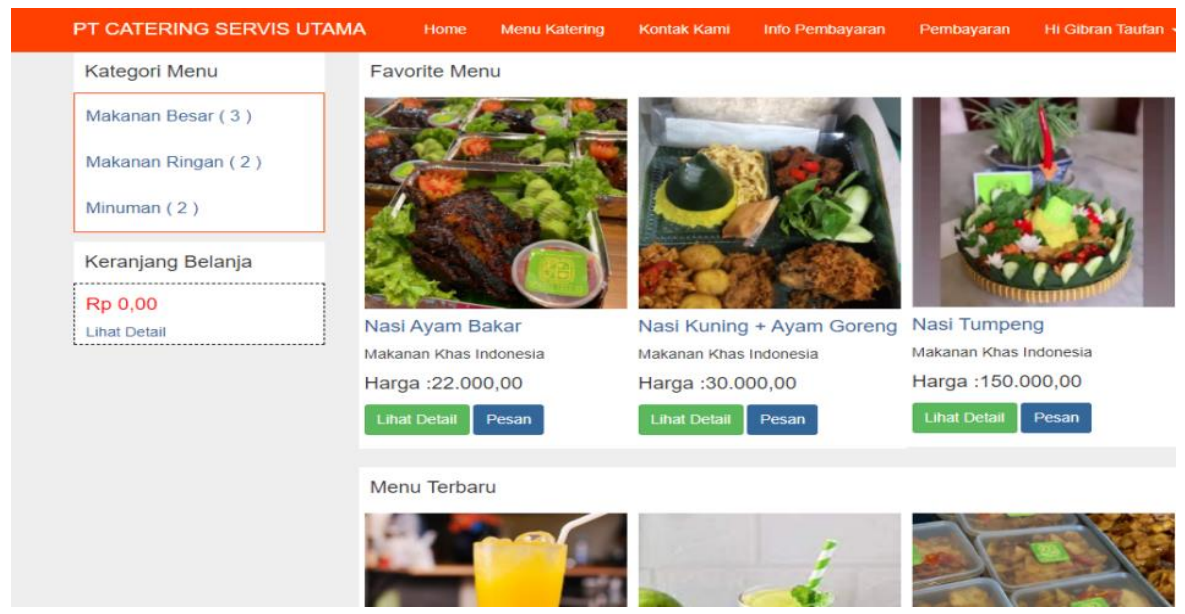

Gambar 4. Tampilan halaman konsumen

b. Tampilan Pendaftaran Konsumen

Tampilan halaman pendaftaran pada PT. Catering Servis Utama.

Konsumen harus login terlebih dahulu, Jika konsumen belum mempunyai data login, konsumen harus register terlebih dahulu.

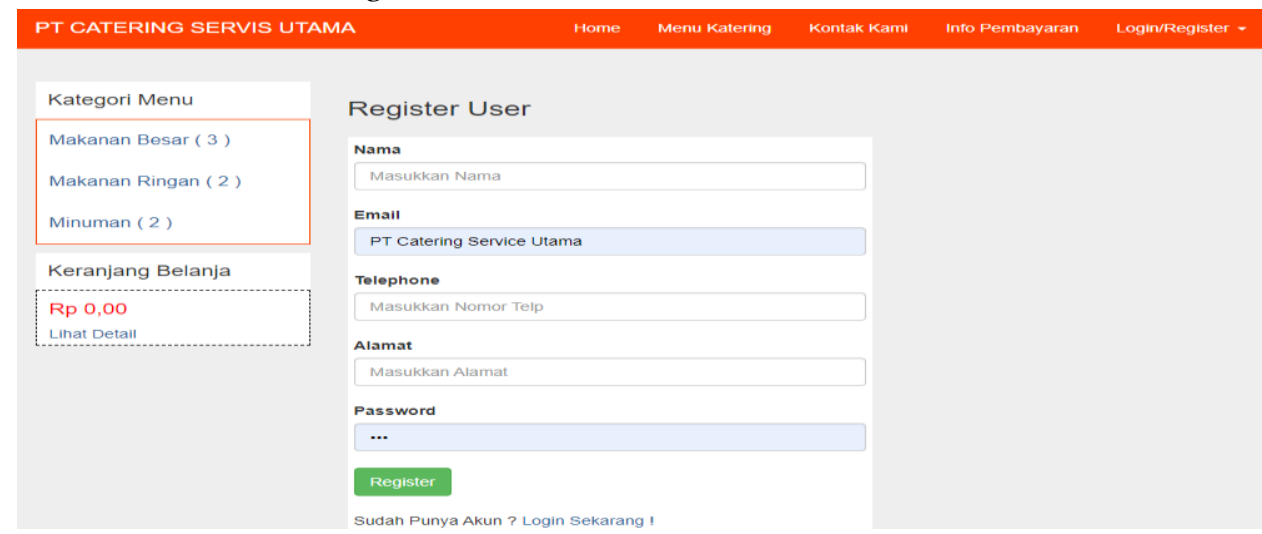

Gambar 5. Pendaftaran konsumen

\section{c. Tampilan Login Konsumen}

Menu ini hanya bisa diakses oleh konsumen untuk login ke web tersebut jika sudah mendaftar.

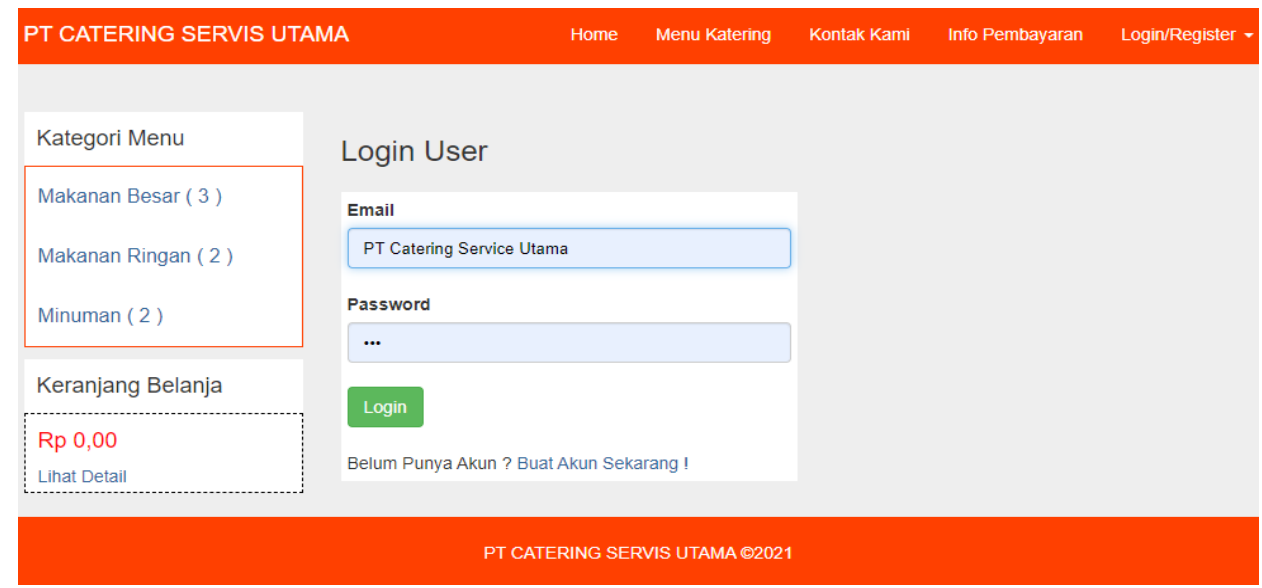

Gambar 6. Login Konsumen 


\section{d. Tampilan Halaman Pemesanan Konsumen}

Tampilan halaman pemesanan pada PT. Catering Servis Utama. Konsumen harus ke menu pesanan terlebih dahulu setelah itu konsumen langsung memesan. Sesudah itu konsumen langsung di alihkan ke total keranjang belanja.

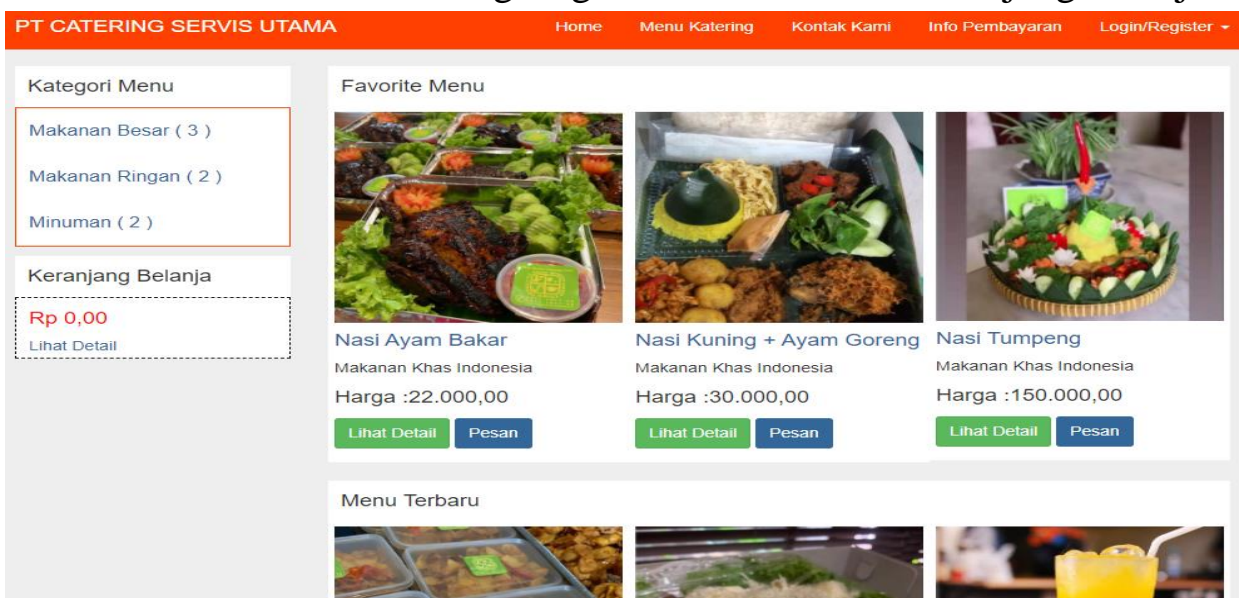

Gambar 7. Tampilan halaman pemesanan konsumen

e. Tampilan Halaman Pembayaran Konsumen

Tampilan halaman pembayaran pada PT. Catering Servis Utama, konsumen langsung memilih menu pembayaran, jika konsumen sudah melakukan pemesanan.

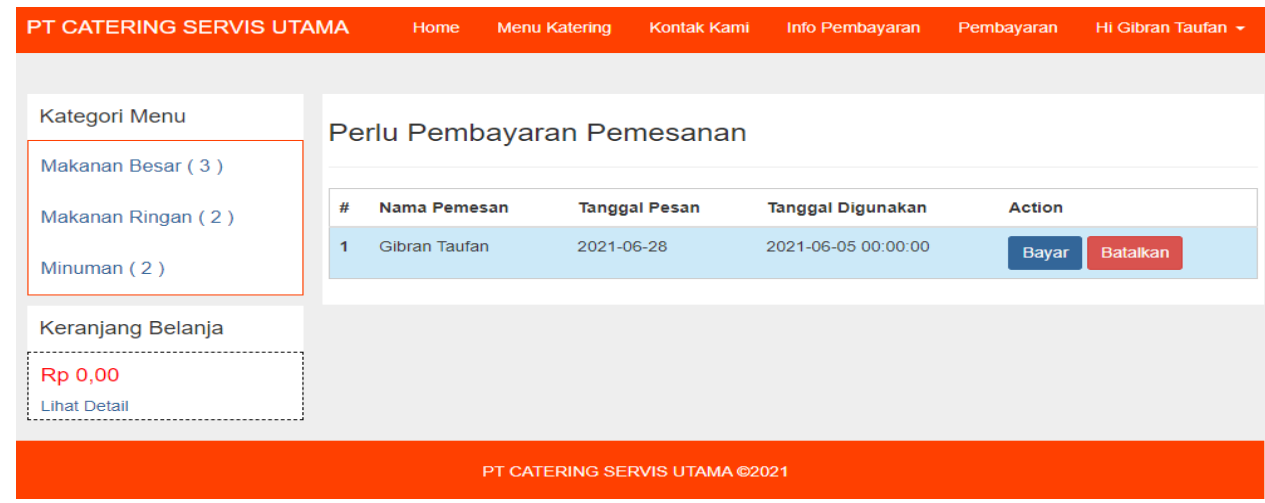

Gambar 8. Tampilan halaman pembayaran konsumen

f. Tampilan Login Admin

Menu pemesanan catering ini digunakan untuk login admin 


\section{Silahkan login}

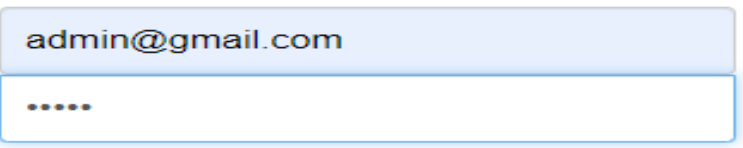

\section{Login}

Gambar 9. Tampilan Login admin

\section{g. Tampilan Halaman Admin Pesanan}

Menu pemesanan catering ini admin dapat melihat data pesanan dari konsumen.

\begin{tabular}{|c|c|c|c|c|c|c|c|c|}
\hline \multicolumn{9}{|c|}{ Daftar pesanan Masuk (3) } \\
\hline \# & Nama Pemesan & Tanggal Pesan & Tanggal Digunakan & Telephone & status & * & & \\
\hline 1 & Gibran Taufan & 2021-06-18 & 2021-06-25 00:00:00 & 081382135145 & belum lunas & Detail & Edit & Delete \\
\hline 2 & Ginanda Walidain & 2021-06-17 & 2021-06-24 09:00:00 & 081219481009 & lunas & Detall & Edit & Delete \\
\hline 3 & Gibran Taufan & 2021-06-17 & 2021-06-20 12:00:00 & 081382135145 & Iunas & Detail & Edit & Delete \\
\hline
\end{tabular}

Gambar 10. Tampilan halaman admin pesanan

h. Tampilan Halaman Admin Pembayaran

Menu pemesanan catering ini admin dapat melihat data transaksi yang telah dibayar oleh konsumen.

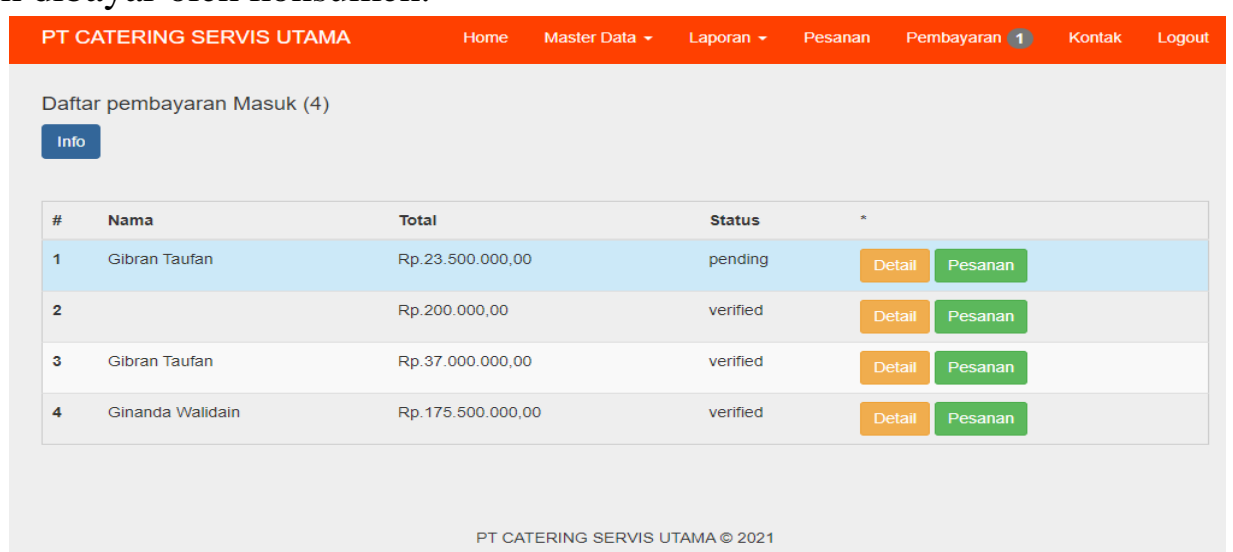

Gambar 11. Tampilan Halaman Admin Pembayaran

i. Tampilan Halaman Laporan Pemilik 
Menu ini hanya bisa diakses oleh pemilik catering untuk melihat hasil laporan pemasukan dan pengeluaran PT Catering Service Utama.

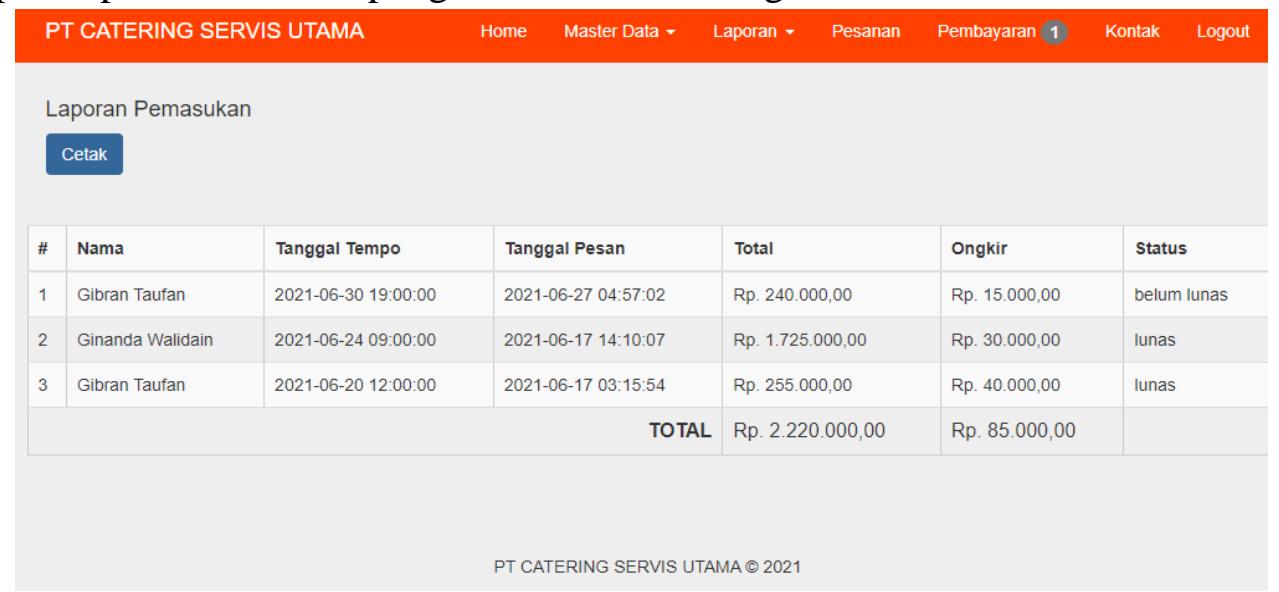

Gambar 12. Tampilan cek nilai

\section{Pengujian}

Pengujian dilakukan untuk mengetahui apakah fungsi yang telah dibuat berjalan sesuai dengan yang diinginkan.

a. Rencana pengujian

Tabel 3. Rencana Pengujian

\begin{tabular}{cll}
\hline No. & \multicolumn{1}{c}{ Item Yang Diuji } & \multicolumn{1}{c}{ Jenis Pengujian } \\
\hline 1 & Halaman & Black Box \\
\hline 2 & Pengolahan Data Pendaftaran & Black Box \\
\hline 3 & Pengolahan Data Pemesanan & Black Box \\
\hline 4 & Pengolahan Data Pembayaran & Black Box \\
& & \\
\hline 5 & Pengolahan Data laporan & Black Box \\
\hline
\end{tabular}

b. Hasil Uji

Tabel 4.

Hasil Uji Halaman Konsumen

\begin{tabular}{llc}
\hline & \multicolumn{1}{c}{ Hasil Uji } & \\
\hline \multicolumn{1}{c}{ Skenario } & \multicolumn{1}{c}{ Kesimpulan } & Hasil \\
\hline $\begin{array}{l}\text { Konsumen membuka } \\
\text { halaman web }\end{array}$ & Muncul halaman & Tampil \\
& home & (Berhasil)
\end{tabular}


Tabel 5.

Hasil Uji Pendaftaran Konsumen

\begin{tabular}{llc}
\hline \multicolumn{1}{c}{ Skenario } & \multicolumn{1}{c}{ Hesimpulan } & Hasil \\
\hline $\begin{array}{l}\text { Input data dan } \\
\text { password sesuai data }\end{array}$ & $\begin{array}{l}\text { Muncul halaman } \\
\text { Pemesanan dan } \\
\text { halaman }\end{array}$ & $\begin{array}{c}\text { Login } \\
\text { (Berhasil) }\end{array}$ \\
\hline
\end{tabular}

Tabel 6.

Hasil Uji Pemesanan Konsumen

\begin{tabular}{llc}
\hline \multicolumn{1}{c}{ Skenario } & \multicolumn{1}{c}{ Kasil Uji } \\
\hline Masuk ke menu & Muncul menulan lakukan & Lihat detail dan \\
Pilih menu makanan & pesan. & pesan \\
dan lihat detail makanan & & (Berhasil) \\
\hline
\end{tabular}

Tabel 7.

Hasil Uji Pembayaran Konsumen

\begin{tabular}{llc}
\hline \multicolumn{3}{c}{ Hasil Uji } \\
\hline \multicolumn{1}{c}{ Skenario } & Kesimpulan & Hasil \\
\hline Bayar Jumlah yang & Muncul menu & Tampil Bayar \\
ditampilkan & pembayaran & dan Batal \\
& & ( Berhasil) \\
\hline
\end{tabular}

\section{Kesimpulan}

Berdasarkan hasil analisa, implementasi serta pengujian pada sistem pemesanan catering berbasis web pada PT Catering Service Utama disimpulkan dengan adanya sistem pemesanan catering ini untuk mempermudah dalam hal pemesanan. Dengan adanya sistem pemesanan catering ini dapat membantu penjualan dan pemesanan pada PT Catering Service Utama lebih efisien. 
Gibran Taufan, Nina Meliana

\section{BIBLIOGRAFI}

Abdul Kadir 2002. Pengenalan Sistem Informasi. Yogyakarta: Andi Yogyakarta Google Scholar.

Azhar Susanto 2013 Sistem Informasi Akuntansi. Bandung: Lingga Jaya. Hal 22 Google Scholar.

Azhar Susanto, 2004, Sistem Informasi Akuntansi Edisi Pertama, Lingga Jaya, Bandung. Hal 46 Google Scholar

Ian Sommerville (2011), Socio-technical systems: From design methods to systems engineering. Jurnal Intracting With Computer. Google Scholar.

Sutarman 2009 Pengantar teknologi Informasi. Jakarta: Bumi Aksara.Hal 5 Google Scholar.

Jogiyanto, 2009. Sistem Informasi Manajemen. Yogyakarta: Penerbit Andi. Hal 34 Google Scholar.

Pemasaran Jasa Catering (2017, Maret 23). Definisi Jasa Catering. http://rohma38.blogspot.com/2017/03/definisi-jasa-catering.html. Google Scholar. 